\title{
Islam en mensenrechten: gaat dat nog lukken?
}

\author{
Maurits Berger
}

Op het terrein van mensenrechten is al decennia in toenemende mate een discussie gaande tussen degenen die vasthouden aan de rechten zoals vastgelegd in internationale verdragen, en degenen die menen dat deze verdragen gedicteerd zijn door een westers individualisme en geen recht doen aan andere partijen dan het individu, zoals de gemeenschap, of God. Deze discussie dreigt een verdeling aan te brengen tussen enerzijds het Westen, en anderzijds de landen die meer nadruk willen leggen op de gemeenschap (Afrika of communistische landen zoals China en, voorheen, de Sovjet-Unie) of op de godsdienst (met name moslimlanden).

Dit heeft bij diverse mensenrechtenjuristen en -activisten geleid tot de verzuchting dat de lat wellicht minder hoog gelegd moet worden en men zou moeten uitgaan van een minimumstandaard. Voor sommigen beperkt deze standaard zich vooral tot het tegengaan van onmenselijke behandeling. ${ }^{1}$ Voor anderen zou dit minimum een algemene wereldwijde consensus moeten inhouden van pluralisme en tolerantie, en vanuit deze aanvaarding kan men dan een systeem van mensenrechten opbouwen waarbij verschillen tussen landen erkend zijn - kortom, een common ground die losstaat van ideologische, filosofische, godsdienstige of andere grondslagen. $^{2}$

In het navolgende artikel wil ik deze discussie tegen het licht houden van de discussies die gaande zijn binnen het islamitisch denken over mensenrechten. De vraag die centraal staat in dit artikel is of de islam en mensenrechten kunnen samengaan (dus conform de 'maximum'-standaard van de mensenrechtenverdragen) en, zo niet, of er ten minste ruimte is om tegemoet te komen aan bepaalde minimumstandaarden die mondiaal gedeeld kunnen worden.

\section{(On)verenigbaar!}

Voordat we ons gaan verdiepen in de discussie binnen het islamitisch denken over mensenrechten, is er een punt van orde over terminologie. Het is gangbaar om te spreken van 'islam' en 'mensenrechten'. ${ }^{3}$ Maar eigenlijk wordt daarmee een vergelijking gemaakt tussen ongelijke grootheden: 'islam' is een godsdienst die zich bezighoudt met de metafysische relatie tussen gelovigen en hun God, terwijl 'mensenrechten' een specifiek rechtsgebied vormt dat de relatie tussen mensen, en in het bijzonder tussen individu en staat, regelt. Nu bevat de islam ook een stelsel aan rechtsregels, genaamd sharia, waarvan een deel de relaties tussen men-

1 M. Ignatieff, Human Rights as Politics and as Idolatry, Princeton 2001, p. 173.

2 Joshua Cohen noemt dit 'justificatory minimalism'; zie J. Cohen, 'Minimalism About Human Rights: The Most We Can Hope For?', The Journal of Political Philosophy 2004, 2, m.n. p.193-94).

3 De meeste academische Engelstalige literatuur over dit onderwerp gebruikt deze twee termen in de titel. 
sen onderling regelt. Dit nu is het terrein binnen de islam waaraan wij gelegitimeerd de vraag kunnen stellen hoe het zich verhoudt tot de hedendaagse opvattingen over mensenrechten.

Degenen die menen dat de regels van de islam en die van mensenrechten verenigbaar zijn, vormen een minderheid. Een kleine groep moslimintellectuelen meent dat sprake is, kan zijn of zou moeten zijn, van verenigbaarheid tussen deze twee grootheden. Alleen kan dat volgens hen slechts het geval zijn indien de sharia niet wordt gezien als corpus van (oude) regels, maar als een rechtssysteem dat nieuwe regels kan 'vinden'. Een andere groep, die vooral wordt vertegenwoordigd door landen die zichzelf nadrukkelijk als 'islamitisch' zien, menen eveneens dat er sprake kan zijn van verenigbaarheid, maar dan wel op eigen merites: zij propageren de zogenoemde 'islamitische mensenrechten', een conceptuele benadering waarbij het cultuurrelativisme een belangrijke rol speelt. Beide groepen worden later in dit artikel uitgebreid besproken.

De stemmen voor de stelling dat de regels van islam en die van mensenrechten niet verenigbaar zijn, lijken veel luider te klinken. Dat is niet verwonderlijk. De islam en met name zijn juridische uitwerking, de 'sharia', laten zich immers niet overal van hun beste kant zien: sinds enkele decennia zijn wij getuige van de wijze waarop terroristische aanslagen, onderdrukkende regimes en hardvochtig optreden tegen andersdenkenden wordt gelegitimeerd met de islam. Maar los van deze algemene indruk zijn er zowel aan moslimse als aan niet-moslimse zijde ook meer afgewogen oordelen over de onverenigbaarheid van de islam en mensenrechten. Europeanen die menen dat sharia en mensenrechten onverenigbaar zijn, baseren zich vaak op de uitspraak van 2003 van het Europees Hof voor de Rechten van de Mens (EHRM; hierna ook: Hof). Dat oordeelde dat de sharia 'duidelijk afwijkt van de waarden van het [Europees] Verdrag [voor de Rechten van de Mens]’. ${ }^{4}$ De specifieke situatie betrof gedragingen en uitspraken van leden van de toenmalige Turkse Refah-partij die inderdaad duidelijk afweken van het Europees mensenrechtenverdrag. Maar wat schort aan deze uitspraak, is dat de term 'sharia' ongedefinieerd blijft. ${ }^{5}$ Dat is om twee redenen problematisch. Ten eerste is het bevreemdend dat een gerenommeerd juridisch instituut als het Hof zich uitspreekt over exotische terminologie die vreemd is aan Europese rechtssystemen, zonder duidelijk te maken wat het Hof met die term bedoelt. Ten tweede betekent een brede veroordeling van 'de sharia' (waarmee het Hof waarschijnlijk verwijst naar allerlei afschuwelijke praktijken die worden begaan in naam van de islam) tevens de veroordeling van alles wat daaronder valt, inclusief regels voor contracten, begraven en vasten - en dat was vast niet de intentie van het Hof. visie van het Europees Hof op de sharia', Tijdschrift voor Religie, Recht en Beleid 2013, 3. Voor andere beschouwingen over deze uitspraak zie: K. Boyle, 'Human Rights, Religion and Democracy: The Refah Party Case', 1 Essex Human Rights Review 2004, 1; D. Schilling, 'European Islamaphobia and Turkey - Refah Partisi (The Welfare Party) v. Turkey', 26 Loyola Los Angeles Law Rev of Int and Comp Law 2004, 501. 
Deze slordigheid in het gebruik van de term 'sharia' vinden we ook elders bij Europese rechtsinstanties terug. In 2008 bijvoorbeeld, oordeelde het Engelse House of Lords in een Libanese voogdijzaak dat de vrouw die om voogdij van de kinderen had gevraagd 'naar dit land [Engeland; MB] is gekomen als een vluchteling van sharia recht', en dat shariarecht zich kenmerkt als 'arbitrair en discriminatoir'. ${ }^{6}$ Dramatische woorden voor een situatie die eigenlijk veel simpeler lag: in Libanon geldt in geval van familierecht het religieus recht (sharia) ${ }^{7}$ van de betrokken partij, en in het geval van moslims is dat het islamitisch familierecht, dat duidelijke regels heeft over de voogdijverdeling van de kinderen na echtscheiding. Het House of Lords had zich negatief kunnen uitlaten over de specifieke regelingen van dit recht, maar koos in plaats daarvan een algemene veroordeling van 'de sharia'.

Op grond van dit algemene en feitelijk onjuiste gebruik van terminologie komen we dus niet tot nadere inzichten over wat er nu zo problematisch is aan deze regels van de islam, ofwel 'sharia'. Overigens is dit gebrek aan helderheid en nuance niet kenmerkend voor de westerse benadering; aan islamitische zijde kan men er ook wat van. Daar hoort men eveneens met regelmaat de stelling dat sharia en mensenrechten niet samengaan, maar dan met de argumentatie dat mensenrechten 'westers' zouden zijn - waarbij de impliciete aanname is dat 'sharia' niet westers is, en mensenrechten en sharia 'dus' tegenpolen zijn. Een voorbeeld hiervan is de speech die de Iraanse ambassadeur bij de Verenigde Naties, Sa'id Raja'i Khorasani, hield in 1983:

'Verdragen, verklaringen en resoluties of beslissingen van internationale organisaties die in tegenspraak zijn met de islam, hebben geen geldigheid in de Islamitische Republiek van Iran. (...) De Universele Verklaring voor de Rechten van de Mens, dat een seculier begrip van joods-christelijke waarden vertegenwoordigt, kan niet worden toegepast door moslims en is niet in overeenstemming met het systeem. [Iran] zal daarom niet aarzelen om de bepalingen hiervan niet na te komen, omdat het moet kiezen tussen het nakomen van de goddelijke wet van het land of het nakomen van seculiere verdragen.' (vertaling door de auteur) ${ }^{8}$

Deze toespraak was weliswaar gehouden in de turbulente jaren vlak na de Iraanse Revolutie (1980), en de inhoud ervan is inmiddels al weer achterhaald. Maar het geeft wel een interessant inzicht in de redeneringen die nog steeds worden gebezigd in het afwijzen van internationale mensenrechten als een 'westers' of zelfs 'joods-christelijk' construct.

6 House of Lords (Verenigd Koninkrijk) 22 oktober 2008 (EM (Lebanon)/Secretary of State for the Home Department), House of Lords [2008] UKHL64: 'The appellant came to this country as a fugitive from Shari'a law.' En: '(...) the arbitrary and discriminatory character of the rule of Sharia law.'

7 De term 'sharia' staat voor religieus recht: men spreekt in het Arabisch daarom van 'sharia islamiya' en 'sharia masihiya', respectievelijk 'islamitisch religieus recht' en 'christelijk religieus recht'.

8 U.N. Doc. A/C.3/39/SR.65, T 95, 1984. 
Het bevreemdende is nu dat enerzijds deze retoriek wordt gehanteerd, terwijl anderzijds veel moslimlanden aangesloten zijn bij internationale mensenrechtenverdragen. We lijken dus verstrikt te zitten in een spraakverwarring waar we eerst uit moeten komen alvorens de rechtsvergelijkende vraag van sharia en mensenrechten te kunnen beantwoorden.

\section{Islam of sharia, theorie of praktijk?}

Het feit dat een land een moslimmeerderheid als bevolking heeft, of zich als 'islamitisch' manifesteert, wil nog niet zeggen dat de schending van mensenrechten in dat land worden gelegitimeerd met de islam, of dat zij gebeuren op basis van de sharia. Vaker is het tegendeel het geval: de meeste moslimmeerderheidslanden hebben weinig tot geen sharia. ${ }^{9}$ De mensenrechtenschendingen in dergelijke landen staan dan los van religieuze overwegingen. Sterker nog: de onderdrukking van autoritaire regimes in deze landen is juist een reden voor oppositiekrachten om de sharia in te roepen als baken van rechtvaardigheid. ${ }^{10}$

Als we ons beperken tot de enkele landen of organisaties die zich nadrukkelijk legitimeren met de islam of zich beroepen op sharia, dan is nog steeds de vraag of we daadwerkelijk met sharia te maken hebben. De systemen van landen als Iran en Saoedi-Arabië, of de praktijken van de taliban, ISIS, Boko Haram en soortgelijke organisaties, zijn overduidelijk strijdig met iedere vorm van mensenrechten. Maar veel (gelovige) moslims wijzen dit soort systemen en praktijken evenzeer af omdat die volgens hen strijdig zijn met de sharia zelf. ${ }^{11}$ Hiermee raken we echter in een moeizame welles-nietes argumentatie over wat wel of geen sharia zou zijn. De taliban en ISIS beroepen zich nadrukkelijk op de islam en sharia, net zo goed als moslimfeministen en -democraten dat doen. En er zijn diepgewortelde tradities, zoals vrouwenbesnijdenis (bekend als FGM: female genital mutilation) of eerwraak, die worden gerechtvaardigd met de islam, terwijl religieuze autoriteiten nadrukkelijk zeggen dat dat niet het geval is (zo houdt meer dan $90 \%$ van de Egyptische vrouwelijke bevolking - zowel christelijk als islamitisch - vast aan de traditie van vrouwenbesnijdenis, ook al hebben de staatsmoefti en de koptische paus herhaaldelijk verklaard dat deze gewoonte niets met deze religies te maken heeft $\left.{ }^{12}\right)$.

Om de discussie over de 'ware' sharia niet nodeloos ingewikkeld te maken zullen we in dit artikel de term 'sharia' op twee manieren bezien: als een (oude) rechtswetenschap en als een (moderne) rechtspraktijk. Met rechtswetenschap bedoel ik

9 J.M. Otto (red.), Sharia Incorporated. A Comparative Overview of the Legal Systems of Twelve Muslim Countries in Past and Present, Leiden 2010.

10 Zie o.a. P. Mandaville, Islam and Politics, London 2014, p. 270 e.v., M.S. Berger, Sharia: Islam tussen Recht en Politiek, Den Haag 2006, p. 60 e.v..

11 Een voorbeeld is de 'Open Letter to Al-Baghdadi', een online verklaring waarin meer dan honderd moslimgeleerden uit de hele wereld de praktijken van ISIS veroordelen als strijdig met de islam en sharia (zie www.lettertobaghdadi.com).

12 Zie o.a. A. Abd Al Hadi, 'Female Genital Mutilation in Egypt', in: M. Tursh (red.), African Women's Health, Trenton 2000, p.145-166. 
het eeuwenoude systeem van rechtsgeleerd recht dat methodieken heeft ontwikkeld om tot rechtsvinding te komen. ${ }^{13}$ Relevant voor onze navolgende discussie is dat in de hedendaagse wens om te komen tot toepassing van sharia grofweg twee stromingen zijn ontstaan onder moslimgeleerden en intellectuelen: de conservatieven, die op 'extreem positivistische wijze' vasthouden aan de regels waartoe men in de afgelopen eeuwen met behulp van het rechtsgeleerde recht is gekomen, ${ }^{14}$ en de revisionisten, die zich niet richten op de regels maar juist op de rechtsgeleerde methodes en deze opnieuw willen toepassen, met als mogelijk gevolg dat men tot andere regels komt.

Met rechtspraktijk doel ik op alle hedendaagse praktijken die plaatsvinden en die worden gelegitimeerd met de sharia. Ook hier zien we een waaier aan uitvoeringen, van de barmhartige weldoener in een arme achterbuurt tot de wrede gewelddadigheid van Boko Haram. Een deel van de minder aangename praktijken vindt vooral plaats in zogenoemde 'falende staten' en in gebieden waar rechteloosheid heerst en de invloed van de centrale staat afwezig is. Aangezien in de mensenrechten de staat een centrale rol speelt, zullen we in dit artikel deze situaties buiten beschouwing laten.

Aan de hand van de tweedeling tussen rechtswetenschap en rechtspraktijk zullen we in de volgende paragrafen nagaan of en in hoeverre sharia en mensenrechten maximaal of minimaal verenigbaar zijn. In de paragraaf 'Theorie: de staat en het individu' zullen we eerst enkele conceptuele kwesties bespreken die van belang zijn voor ons begrip van het islamitische mensenrechtendebat. In de daaropvolgende paragraaf, 'Praktijk - de maximumstandaard', breiden we de discussie uit en zullen we enkele van de meest kenmerkende mensenrechten vergelijken met de sharia als rechtspraktijk en rechtswetenschap. In de laatste paragraaf, 'Toekomst - maximaal of minimaal?', zal ten slotte worden ingegaan op de actuele islamitische discussie die beoogt mensenrechten en sharia te verenigen.

\section{Theorie: de staat en het individu}

Mensenrechten zoals geformuleerd en geconcipieerd in internationale verdragen gaan uit van de verhouding tussen staat en individu, waarbij het individu (mensen)rechten heeft die de staat dient te respecteren. De relatie tussen staat en individu ligt iets anders in het klassieke islamitische recht. In deze relatie is er namelijk nog een derde partij, God, die als de ultieme spelverdeler van rechten optreedt. ${ }^{15}$ Volgens sommige critici is daarmee iedere discussie over mensenrechten eigenlijk al kansloos, want men spreekt dan eigenlijk 'niet van rechten van

13 K. Abou El Fadl, Reasoning with God: Reclaiming Shari'ah in the Modern Age, Washington DC 2014; W.B. Hallaq, Shari'a: Theory, Practice, Transformations, Cambridge 2009; M.H. Kamali, Shariah Law: An Introduction, Londen 2008.

14 Zie o.a. A. El Fadl, 'The Human Rights Commitment in Modern Islam', in: J. Runzo \& N. Martin (red.), Human Rights and Responsibilities, Oxford 2003, p. 149.

15 In de woorden van een gerenommeerde auteur op dit gebied, Majid Khadduri: 'Human rights in Islam are the privilege of Allah (God), because authority ultimately belongs to Him' ('Human Rights in Islam', The ANNALS of the American Academy of Political and Social Science, 1946, p. 77-78). 
mensen, maar gunsten van God'. ${ }^{16}$ Maar laten we deze driehoeksrelatie van individu-staat-God toch aan een nadere analyse onderwerpen.

De taak van de staat in het islamitisch recht is om het welzijn van de mensen te bevorderen. Tot zover is de overeenkomst met hedendaagse rechtsopvattingen gelijk. Maar de staat bevordert dit welzijn niet naar eigen goeddunken: hij is daartoe gehouden door de Regels van God, de sharia. De sharia fungeert als de universele, want goddelijke rechtsorde waaraan de staat is onderworpen. De staat kan derhalve volstaan met handhaving van de sharia. ${ }^{17}$ Men zou in die zin kunnen spreken van een rechtsstaat, met dien verstande dat de islamitische staat, anders dan moderne democratieën, geen enkele zelfstandige invloed heeft op die rechtsstaat.

In deze constructie is God degene die de rechten toekent. Enkele van deze rechten zijn expliciet vermeld in de Koran. Deze kunnen de relatie betreffen tussen mensen (huquq al-ibad of huquq al-adamiyyin), zoals het recht van de man op polygamie, of het recht van de vrouw om (ook) te mogen erven. Andere rechten betreffen de relatie tussen mens en God (huquq Allah), zoals de straffen op vijf met name genoemde misdaden ${ }^{18}$ (er zijn natuurlijk veel meer misdaden, maar door deze zo duidelijk te vermelden in de Koran zou God te kennen hebben gegeven dat degenen die zich daaraan schuldig maken een speciaal vergrijp jegens God zelf begaan). De islamitische rechtsgeleerden hebben in het goddelijk systeem van de sharia echter ook een breder spectrum aan rechten gezien: deze voorziet in drie categorieën van belangen die het welzijn van de mens dienen, namelijk dat wat noodzakelijk is, dat waar behoefte aan is, en dat wat het leven plezierig maakt. De staat dient deze belangen in deze volgorde te behartigen. Daarbij staan de 'noodzakelijke belangen' voorop, en die zijn op hun beurt onderverdeeld in de belangen van religie, leven, intellect, familie en eigendom. ${ }^{19}$ Een veelgebruikt voorbeeld is het volgende: als een moslim van dorst dreigt om te komen in de woestijn en een fles wijn vindt, dan verbiedt zijn religie hem die te drinken, maar diezelfde religie stelt het leven als hoger belang en dat vereist dat hij die fles wel moet drinken.

Een stap dieper in deze conceptuele beschouwingen brengt ons bij de aard van het mensen-'recht'. De klassieke islamitische bronnen gebruiken daarvoor het woord haqq, dat gevoeglijk wordt vertaald als 'recht', en aan de rechtenfaculteiten van Arabische landen die het moderne recht doceren ook als zodanig wordt gebruikt. Maar de vraag is of met haqq in de oude islamitische teksten wel hetzelfde werd bedoeld als in het moderne jargon. Wanneer bijvoorbeeld de Koran spreekt van

16 J. Donnelly, 'Human Rights and Human Dignity: An Analytic Critique of Non-Western Conceptions of Human Rights', The American Political Science Review 1982, 2, p. 307.

17 Coulson, 'The State and the Individual in Islamic Law', 6 Internationall \& Comparative Law Quarterly 1957, p. 49-50.

18 Dat zijn: diefstal, straatroof, alcoholgebruik, voor- of buitenhuwelijkse seksuele relaties en de valse beschuldiging van dergelijke relaties. Volgens sommige geleerden is afvalligheid de zesde misdaad.

19 Voor nadere toelichting zie o.a. M.H. Kamali, Maqasid al-Shari'ah made simple (Occasional paper Series 13), Londen/Washington: The International Institute of Islamic Thought 2008; K. Abou El-Fadl, 'The Human Rights Commitment in Modern Islam', in: J. Runzo \& N. Martin (red.), Human Rights and Responsibilities, Oxford 2003, p. 149. 
een haqq van God, dan is dat iets waar de mensheid aan moet voldoen als verplichting jegens God. En het haqq van de man om met meer dan één vrouw te mogen trouwen is een zelfstandig recht dat hij tegen niemand hoeft in te roepen, maar dat hem evenmin ontnomen mag worden. Evenzo kan het haqq van de mensen op welzijn bezien worden als een verplichting van de overheid om dat te bewerkstelligen. Kortom, de term haqq is juridisch complex, en niet zonder meer vertaalbaar naar de huidige situatie. Sommige auteurs gaan zelfs zover door te stellen dat het islamitisch recht eigenlijk geen rechten kent, maar alleen verplichtingen. ${ }^{20}$

Daargelaten hoe we de terminologie moeten interpreteren, rijst vervolgens de vraag in hoeverre de rechten die gelden tussen de mensen (huquq al-ibad of huquq al-adamiyyin) aangemerkt kunnen worden als mensenrechten, of op zijn minst aanleiding kunnen zijn om een nieuwe, islamitische mensenrechtentraditie te formuleren. ${ }^{21}$ Deze visie wordt bekritiseerd door degenen die menen dat de 'rechten'-relatie in de islam conceptueel wezenlijk anders zou zijn dan het moderne begrip 'mensenrechten'. 22 Volgens deze critici beoogt de islamitische juridische structuur namelijk niet om individuen eigen rechten te geven jegens de staat: het individu is net zo gehouden om navolging te geven aan de door God gegeven rechten als de staat. ${ }^{23}$ Het individu staat niet tegenover de staat, zoals moderne mensenrechtelijke opvattingen suggereren; het individu is een integraal onderdeel van de staat. Of in andere woorden: het individu is een onderdeel van de gemeenschap der gelovigen (umma), en ís als zodanig de staat. ${ }^{24}$ Daar kan weer tegen ingebracht worden dat de opdracht van de staat om het welzijn van de mensen te garanderen een feitelijke situatie creëert waarin de staat tegenover zijn burgers staat, en door hen ter verantwoording geroepen zou kunnen worden. ${ }^{25}$

Deze discussie loopt naadloos over in de discussie over individuele of groepsgebonden mensenrechten. Volgens Donnelly, een gerenommeerde maar ook uitgesproken auteur op dit gebied, is dit een kenmerkend verschil tussen wat hij westerse en niet-westerse mensenrechtentradities noemt. ${ }^{26} \mathrm{Als}$ voorbeelden van deze laatste categorie worden wel 'Afrikaanse', 'socialistische' of 'Chinese' mensenrechtenopvattingen genoemd; die zouden een wezenlijk andere benadering hanteren omdat daarin het belang van het individu onderworpen is aan het belang van de

20 'Human rights exist only in relation to human obligations. Individuals possess certain obligations towards God, fellow humans and nature, all of which are defined by Shariah. When individuals meet these obligations they acquire certain rights and freedoms which are again prescribed by the Shariah' (A. Aziz Said, 'Precept and practice of human rights in Islam', Universal Human Rights 1979, 1, p. 63-80, 73-74).

21 Zie o.a. Abou El-Fadl 2003, p. 49-50.

22 Zie o.a. Coulson 1957, p. 50; Donnelly 1982, p. 303-316.

23 Coulson 1957, p. 50.

24 C. Bassiouni, 'Sources of Islamic Law and the Protection of Human Rights in the Islamic Criminal Justice System', in: C. Bassiouni (red.), The Islamic Criminal Justice System, 1982, p. 3, 23.

25 Dat is de redenering die Khaled Abou El-Fadl lijkt te volgen in zijn 'The Human Rights Commitment in Modern Islam'.

26 Donnelly 1982, p. 311; zie ook J. Donnelly, 'The Relative Universality of Human Rights', Human Rights Quarterly 2007, 2, p. 281-306. 
gemeenschap. ${ }^{27}$ Volgens deze visie zijn de mensenrechten 'zoals gedefinieerd door het Westen' niet 'relevant', of 'ontoepasbaar' op de 'niet-westerse' situatie. ${ }^{28}$ Vaak wordt in deze communautaire visie op mensenrechten ook de islam vermeld, maar die vergelijking gaat niet helemaal op. In de islam heeft ieder individu namelijk een eigen verantwoordelijkheid jegens de regels die God hem of haar heeft opgelegd. Sterker nog, ieder individu heeft tevens de taak om uitvoering te geven aan deze regels. ${ }^{29}$ Theologisch-theoretisch bezien veranderen de regels van God niet voor een moslim die alleen op de Noordpool leeft, of als minderheid in Nederland woont, of burger is van Iran. Deze moslim zal een persoonlijke verantwoordelijkheid dragen jegens God om navolging te geven aan deze regels. De aanwezigheid of tussenkomst van een staat is daarbij in beginsel niet nodig, en kan hoogstens behulpzaam zijn in de facilitering van een collectieve uitvoering van deze regels. ${ }^{30}$ Wat de islamitische rechtsopvattingen onderscheidt van mensenrechten is dus niet het individu als zodanig, maar de soevereiniteit van God. De mate waarin individu en staat onderworpen zijn aan bepaalde, door God opgelegde regels, die onveranderlijk zijn - dáár wringt de schoen. Om die reden moeten wij onze blik dus richten naar de regels en de rechtswetenschap van de islam.

Uit het voorgaande hebben wij al een indruk kunnen krijgen van de complexiteit van de islamitische rechtswetenschap, die nauw verweven is met de theologie. Men kan deze wetenschap flexibel noemen vanwege de interpretatieve mogelijkheden die ze biedt, ${ }^{31}$ maar in de praktijk is deze wetenschap in de loop der eeuwen uitgegroeid tot een gefossiliseerd corpus aan regels die weinig bewegingsruimte biedt. In de navolgende paragraaf zullen wij ingaan op de wijze waarop deze vastgestelde regels van de islamitische rechtswetenschap zich verhouden tot de moderne mensenrechten. In de paragraaf daarna zal de flexibele vorm van deze wetenschap aan bod komen.

\section{Praktijk - de maximumstandaard}

In deze paragraaf zullen we in vogelvlucht enkele van de meest elementaire mensenrechten nagaan - non-discriminatie, vrijheid van religie en lichamelijke integriteit - en per onderdeel bespreken hoe deze zich verhouden tot de vastgestelde regels van de islamitische rechtswetenschap en tot de regels van de hedendaagse rechtspraktijk van moslimmeerderheidslanden. Op grond van dit schetsmatige

27 Zie voor dergelijke argumentatie: A. Legesse over Afrika, E.L. Keenan over de Sovjet-Unie en Shao-Chuan Leng over China in: K.W. Thompson (red.), The Moral Imperative of Human Rights: a World Survey, Washington 1980.

28 A. Pollis \& P. Schwab, 'Human rights: a western construct with limited applicability', in: A. Pollis \& P. Schwab (red.), Human rights: cultural and ideological perspectives, New York 1980, p. xiii-xvi.

29 M. Cook, Commanding Right and Forbidding Wrong in Islamic Thought, Cambridge 2000, p. 583.

30 Om deze reden pleit Abdullahi An-Na'im er ook voor dat een 'islamitische staat' alleen kan bestaan als een seculiere staat, namelijk een staat die niet voorschrijft hoe religieuze voorschriften worden gehandhaafd, maar als een staat die slechts de ruimte biedt aan zijn gelovige burgers om zelf uitvoering te geven aan deze regels (A. An-Na'im, Islam and the Secular State. Negotiating the Future of Shari'a, Harvard 2010).

31 M.S. Berger, 'Sharia, A Flexible Notion', Rechtsfilosofie \& Rechtstheorie 2006, 3. 
overzicht (want meer pretendeert het ook niet te zijn) kunnen wij ons een beter beeld vormen van de schurende kwesties die spelen tussen sharia en mensenrechten.

\section{Gelijkheid en non-discriminatie}

De islamitische rechtswetenschap hanteert een duidelijke hiërarchie waarin de moslimman bovenaan staat, gevolgd door de moslimvrouw, dan de niet-moslim en ten slotte de slaaf. Ongelijkheid is dus een wezenlijk onderdeel van de klassieke islamitische rechtsopvatting. Daarentegen hanteren de meeste hedendaagse moslimlanden grondwetten waarin gelijkheid en non-discriminatie nadrukkelijk zijn opgenomen, en zijn vele daarvan lid van de bekende mensenrechtenverdragen (ofschoon veel moslimlanden daar op bepaalde onderdelen wel voorbehouden hebben gemaakt - hierover later meer). In de wijze waarop de islamitische rechtswetenschap en rechtspraktijk omgaan met het non-discriminatiebeginsel, zullen we de categorieën 'geslacht' en 'religie' hierna apart bespreken.

- Gelijkheid en non-discriminatie op basis van geslacht

De islamitische rechtswetenschap maakt onderscheid tussen islamitische mannen en vrouwen. Dat blijkt bijvoorbeeld uit de regel dat twee vrouwelijke getuigen gelijk zijn aan één enkele mannelijke getuige; dat een moslimman wel met een niet-moslimse vrouw mag trouwen, maar een moslimse vrouw niet met een nietmoslimse man; dat vrouwen andere - naar moderne maatstaven: mindere - rechten geniet in het huwelijk dan de man; dat de vrouw een beperkt en de man een absoluut scheidingsrecht heeft; dat het recht op polygamie is voorbehouden aan de man; dat de zus de helft erft van wat haar broer erft. ${ }^{32}$

Deze voorbeelden komen vooral voort uit het familie- en erfrecht. Aangezien de meeste moslimlanden religieus familierecht hanteren (dat geldt dus ook voor hun christelijke en joodse burgers, zoals wij hiervoor al zagen in het Libanese voorbeeld $^{33}$ ), zijn veel van deze regels ook vandaag de dag nog van toepassing. Met name in het begin van de twintigste eeuw hebben moslimstaten wel geprobeerd daar de harde randjes van af te slijpen. Zo is bijvoorbeeld polygamie wel toegestaan, maar moet in veel moslimlanden de man bij de rechtbank verantwoording afleggen dat hij ieder van zijn vrouwen gelijkelijk en in voldoende welstand zal behandelen, en in sommige landen heeft de eerste vrouw dan het recht van hem

32 Dit zijn bekende regels, die in alle handboeken over islamitisch familierecht zijn terug te vinden. Zie bijv. de hoofdstukken 'Family' en 'Inheritance' in: J. Schacht, Introduction to Islamic Law, Oxford 1964, of de hoofdstukken over familierecht in F.J.A. van der Velden, Inleiding in de shari'a, Den Haag 2016.

33 Ter vergelijking: Egypte kent 1 islamitische, 6 christelijke en 2 joodse familiewetten, Syrië 2 islamitische, 5 christelijke en 1 joodse familiewet (M.S. Berger, 'De doos van pandora: openbare orde en conflictenrecht in Egyptisch familierecht', in: S.W.E. Rutten, Recht van de islam 18, Maastricht: RIMO 2001, p. 99-116; M.S. Berger, 'De rol van religie in het Syrisch conflictenrecht', Tijdschrift voor Familie- en Jeugdrecht 2002, a. 1, p. 13-22.). Dit system is overigens niet beperkt tot moslimmeerderheidslanden: Israël kent de joodse, christelijke en islamitische familiewetten, India de islamitische en de hindoefamiliewet (o.a. M. Galanter \& J. Krishnan, 'Personal Law and Human Rights in India and Israel', Israel Law Review 2000, p. 101-133). 
te scheiden. ${ }^{34}$ Deze aanpassingen gingen niet iedereen snel genoeg, en de moslimwereld kent een lange traditie van vrouwenrechtenbewegingen, die zich lange tijd vergeefs hebben verzet tegen de vrouwonvriendelijke regels van het islamitisch familierecht. Sinds de jaren tachtig echter, zijn veel van deze bewegingen van tactiek veranderd door islamitische argumentatie te gebruiken. ${ }^{35}$ Deze aanpak is succesvol gebleken, zoals het geval was in de nieuwe scheidingswet van 2000 in Egypte: waar de vrouw voor haar scheiding altijd afhankelijk was van haar echtgenoot of de rechter, ${ }^{36}$ kreeg zij nu een zelfstandig scheidingsrecht op basis van een uitspraak van de profeet. $^{37}$

- Gelijkheid en non-discriminatie op basis van religie

Anders dan in het christendom en jodendom erkent de islam het bestaan van niet-moslims. Deze theologische erkenning wordt juridisch uitgewerkt in een tweederangs status van de niet-moslims, waarbij de christenen en joden een meer geprivilegieerde positie hebben dan andere religies. ${ }^{38} \mathrm{Zij}$ worden door de islam erkend als voorlopers van de islam en verdienen als zodanig een 'beschermde status', bekend als dhimmi. De bescherming ziet vooral in de vrijheid van religie (waarover hierna meer), maar voor het overige is vooral sprake van een tweederangs burgerschap, dat men terugziet in allerlei regels: de niet-moslim kan niet zomaar getuigen tegen een moslim; een niet-moslimman mag niet met een moslimse vrouw trouwen; een niet-moslim kan niet erven van een moslim. ${ }^{39}$ Het uitgangspunt van deze regels is 'Islam heerst, en wordt niet overheerst', ofwel dat de niet-moslim nimmer in een positie mag komen dat hij in de hiërarchie boven een moslim staat. ${ }^{40}$ Dus een niet-moslim kan niet het hoofd van het gezin zijn met een islamitische vrouw (andersom kan dat wel), hij kan nimmer president of commandant in het leger zijn, en zijn doodslag van een moslim wordt zwaarder beoordeeld dan de omgekeerde situatie.

Het dhimmi-schap werd in de praktijk onderstreept door kledingvoorschriften en gedragsregels op straat: christenen en joden moesten ieder bepaalde kleuren dra-

34 J. Rehman, 'The Sharia, Islamic Family Laws and International Human Rights Law: Examining the Theory and Practice of Polygamy and Talaq', International Journal of Law, Policy and the Family 2007, 21, 108-127.

35 A. Moors, 'Introduction: Public Debates on Family Law Reform Participants, Positions, and Styles of Argumentation in the 1990s', Islamic Law and Society 2003, 1, p. 1-11; L. Welchman (red.), Women's Rights and Islamic Family Law: Perspectives on Reform, Londen 2004.

36 De khul' is de scheiding waarbij de vrouw aan haar man vraagt om haar te scheiden in ruil voor teruggave van de bruidsgave, en de tatliq is de scheiding waarbij de vrouw aan de rechter vraagt om haar te scheiden op basis van een van de in de wet vermelde gronden (zoals nalatigheid in onderhoud, impotentie, mishandeling).

37 N. Sonneveld, Khul' divorce in Egypt: public debates, judicial practices, and everyday life (thesis), Amsterdam 2009.

38 Deze geprivilegieerde positie geldt ook voor sabaeners en zoroastriërs, maar die zijn inmiddels kleine minderheden geworden.

39 A.M. Emon, Religious Pluralism and Islamic Law. Dhimmis and Others in the Empire of Law, Oxford 2014; A. Fattal, Le statut légal des non-musulmans en pays d' Islam, Beiroet 1958.

40 al-Islām ya ' lū wa lā yu 'lā 'alay-hi. Dit is gebaseerd op Koran 4: 140: 'De Wet ontneemt de ongelovige het zeggenschap over de moslims.' Zie voor uitwerking van dit begrip M. Berger, 'Secularizing Interreligious Law in Egypt', Islamic Law and Society 2005, 3, p. 394-418, i.h.b. p. 396-398. 
gen om hen van elkaar en vooral van de moslims te onderscheiden, en het was hun vaak verboden op straat wapens te dragen of paard te rijden. Deze voorschriften staan niet in de rechtswetenschappelijke teksten, maar waren lokale verordeningen (net zoals de christelijke Europeanen soortgelijke verordeningen hadden ten aanzien van joden en moslims). ${ }^{41}$

Wat we hier voor ogen moeten houden is het onderscheid tussen recht en praktijk: in dit artikel bespreken wij de rechtsregels, maar die konden aanzienlijk verschillen van de sociale werkelijkheid. ${ }^{42}$ Zo bestond de regel dat niet-moslims nimmer in een positie konden komen dat ze macht konden uitoefenen over een moslim, maar niettemin waren er situaties dat de kaliefs in Bagdad of Cordoba joodse lijfartsen of christelijke adviseurs hadden. Omgekeerd genoten moslims en christenen weliswaar juridisch een 'beschermde status', maar hebben zich gevallen voorgedaan van vervolging. ${ }^{43}$

Het dhimmi-schap is sedert de negentiende eeuw afgeschaft. Dat heeft tot gevolg dat de huidige rechtspraktijk van bijna alle moslimlanden uitgaat van burgerschap, ongeacht religie. ${ }^{44}$ In de Arabische wereld heeft dit in de twintigste eeuw geleid tot de ideologie van het pan-arabisme, waarbij nationale eenheid werd gezocht in de gemeenschappelijkheid van de Arabische taal en cultuur, en verschillen op basis van religie nadrukkelijk werden afgewezen. In landen als Pakistan en Libanon gebeurde juist het omgekeerde en probeerde men de politieke vertegenwoordiging van religieuze minderheden te steunen door hen vaste zetels in het parlement toe te kennen. Deze ideologie van nationale eenheid gebaseerd op secularisme, die in de jaren vijftig en zestig nog zeer sterk was, werd vanaf de jaren tachtig ingehaald door die van de islam, die inmiddels door steeds meer moslimlanden als nationale identiteit wordt omarmd. Dat had op zichzelf niet onmiddellijk consequenties voor de rechtspositie van niet-moslimse burgers, maar het schiep wel een nationale sfeer waarbij de moslims zich meer eigenaar van het land voelen ten koste van de niet-moslims.

In termen van rechtsregels is in hedendaagse moslimmeerderheidslanden het onderscheid op basis van religie vooral nog aanwezig in het familierecht. Dat discriminatoire karakter geldt dus niet alleen voor de islamitische, maar voor alle religieuze familiewetten die in dergelijke landen van toepassing zijn. In het geval van de islamitische familiewetten in deze landen treft men dus vaak de regel dat een niet-moslimse man niet met een moslimse vrouw mag trouwen en dat een niet-moslim niet kan erven van een moslim. In veel moslimlanden geldt ook de regel dat het presidentschap is voorbehouden aan een moslim, en in landen waar meerdere religieuze familiewetten naast elkaar bestaan is het omstreden of een christelijke rechter wel het islamitisch familierecht kan toepassen (andersom wordt dat geen probleem geacht).

41 Voor de christenen en joden onder moslimgezag, zie bijv. D. Quataert, The Ottoman Empire 1700-1922, Cambridge 2005, p. 148. Voor moslims onder christelijk gezag, zie bijv. J.M. Powell, Muslims under Latin Rule. 1100-1300, Princeton 1990, p. 190-191.

42 L. Chabry \& A. Chabry, Politique et minorites au Proche-Orient, Parijs 1984; Y. Courbage \& P. Fargues, Christians and Jews Under Islam, Londen 1997.

43 Powel 1990; Qaetaert 2005.

44 Een uitzondering is bijv. Saoedi-Arabië, waar alleen moslims burger kunnen zijn. 


\section{Vrijheid van religie en vrijheid van opinie over religie}

In de islamitische rechtswetenschap bestaat de vrijheid van religie vooral voor niet-moslims: de moslimse autoriteiten lieten zich weinig gelegen liggen aan de religies van niet-moslims, en bemoeiden zich niet met de dogma's of de inrichting daarvan. Deze vorm van religieuze tolerantie kwam voort uit het Koranisch voorschrift 'Geen dwang in religie'45 en in de juridische stelregel 'Laat ze [de ongelovigen; MB] en wat ze geloven'. ${ }^{46}$ Waar het dhimmi-schap enerzijds werd gekenmerkt door civielrechtelijke ongelijkheid, zoals wij hiervoor zagen, was het andere kenmerkende aspect ervan dat niet-moslims volledig vrij werden gelaten in de beoefening van hun religie, zelfs als dat aanstootgevend was voor moslims (zoals het gebruik van wijn en varkensvlees) ${ }^{47}$ Deze vrijheid ging zelfs zover dat niet-moslims regelgevende en rechtsprekende autonomie kregen over alle kwesties die betrekking hadden op hun religie. Aangezien familierecht als onlosmakelijk onderdeel werd gezien van religie, werd het de joodse en christelijke gemeenschappen toegestaan hun eigen familiewetten en eigen familierechtbanken te hebben. ${ }^{48}$

Deze vrijheid had overigens twee beperkingen. De eerste was dat niet-moslims zich nimmer kritisch konden uitlaten over de islam, hoezeer deze religie ook strijdig werd geacht met de eigen religieuze dogma's. ${ }^{49}$ De tweede beperking betrof de situatie van de bekering. Een bekeerling zal immers altijd door zijn vorige geloofsgenoten aangezien worden als afvallige, en door zijn nieuwe geloofsgenoten als nieuwe gelovige. Maar in het geval van burgers onder islamitisch gezag werd de bekering van de christen tot de islam erkend als een geldige bekering (en had de afvalligheid van het christelijk geloof geen geldigheid), terwijl de moslim die zich bekeerde tot het christendom werd beschouwd als afvallige die zwaar gestraft moest worden (en had de bekering tot het christelijk geloof geen geldigheid).

De relatieve vrijheid van religie die de niet-moslims genoten, gold niet voor de moslims. Waar de moslims zich niets gelegen lieten liggen aan schisma's en ketterijen binnen de christelijke en joodse gemeenschappen - dat werd beschouwd als hun eigen, interne problemen -, waren zij een stuk minder tolerant naar dergelijke verschijnselen binnen de islam. De moslims dienden zich te houden aan de voorschriften van de islam die, afhankelijk van tijd en plaats, meer of minder strikt nageleefd dienden te worden. Afvalligheid of ketterij werd bijvoorbeeld absoluut niet geduld, net zomin als kritiek op geloofsleerstellingen van de islam ${ }^{50}$

46 Natrukahum wa ma yadinuna. Zie voor verwijzingen naar Arabische bronteksten van het islamitisch recht: M.S. Berger, 'Public Policy and Islamic Law: The Modern Dhimmi in Contemporary Egyptian Family Law', Islamic Law and Society 2001, 1, p. 88- 136, i.h.b. p. 92.

47 In de uitgebreide academische literatuur over dhimmi-schap wordt het aspect van religieuze tolerantie met name door moslimse auteurs benadrukt: K. Elgeddawy, Relations entre systemes confessionnels et laique en Droit International Prive, Parijs 1971; Y. al-Qaradawi, Non-Muslims in the Islamic society [vert. K.M. Hamad \& S.M.A. Shah, Indianapolis 1985 (oorspr. titel: Ghayr al-Muslimin fi al-Mujtama' al-Islami, Caïro: Maktabat Wahba 1977)].

48 Zie o.a. Fattal 1958; Berger 2005.

49 M. Hashim Kamali, Freedom of Expression in Islam, Londen 1997, p. 130-2.

50 Kamali 1997, p. 212-31. 
(waarbij ook 'opbouwende kritiek' of suggesties voor herinterpretatie konden leiden tot de beschuldiging van bid'a, ofwel ongewenste vernieuwing). ${ }^{51}$

In de hedendaagse rechtspraktijk van moslimmeerderheidslanden zien we een gemengd beeld. Enerzijds staan religieuze tolerantie en vrijheid van religie hoog in het vaandel van de meeste moslimlanden. Anderzijds zijn deze waarden enorm onder druk komen te staan door de toenemende invloed van islamitisch fundamentalisme. Die druk manifesteert zich op drie niveaus. De eerste is op maatschappelijk niveau: beschuldigingen van on-islamitische uitspraken of gedrag hebben in veel gevallen geen wettelijke grondslag, maar kunnen enorme sociale repercussies hebben, zoals vele intellectuelen, schrijvers, filmmakers en filmacteurs hebben mogen ervaren.

Relevanter voor de discussie is het niveau van de staat. Diverse moslimlanden hebben bezwaar tegen de interpretatie van 'vrijheid' als dit ook zou betekenen dat een moslim zich kan bekeren tot een andere religie, of geen religie (meer) zou hebben. Niettemin noemt het Internationaal Verdrag inzake burgerrechten en politiek rechten in artikel 18 het recht om deze vrijheid 'te hebben of te aanvaarden'. Moslimlanden, zoals Algerije en Saoedi-Arabië, hanteren echter nog steeds een strafbaarheid op de afvalligheid van de islam: het 'aanvaarden' van een andere religie door een moslim is in deze landen derhalve verboden. Toch zien zij die strafbaarstelling niet als een inbreuk op het door hen geratificeerde verdrag. Zij hanteren het standpunt dat de vrijheid van religie bij hen afdoende is beschermd. In hun interpretatie staat 'bescherming' van de islam namelijk gelijk aan het voorkomen dat mensen dit geloof afwerpen. ${ }^{52}$ Maar ook moslimlanden die dergelijke verboden formeel niet hebben, kunnen die feitelijk wel hanteren door bijvoorbeeld onvoldoende bescherming te verlenen tegen beschuldigingen van afvalligheid, of door administratieve obstakels op te werpen om bekering van moslims tot een ander geloof onmogelijk te maken. ${ }^{53}$

En daar tussenin, waar maatschappij en staat elkaar raken, bevindt zich het derde niveau, de rechtspraak. Daar blijkt dat de rechterlijke macht in veel moslimmeerderheidstaten bewegen van een areligieuze houding naar een pro-islamitische houding. Waar het in Pakistan in de seculiere jaren vijftig en zestig volgens het hoogste gerechtshof niet uitmaakte wat een 'echte' moslim betekende, zag hij dat vanaf de jaren tachtig aanmerkelijk anders. ${ }^{54}$ Dezelfde verschuiving was zichtbaar bij het Egyptische Hof van Cassatie, dat in 1994 oordeelde dat hoezeer iemand zichzelf ook als gelovig moslim bestempelde, deze persoon als afvallige aangemerkt moest worden omdat zijn opvattingen over de islam afweken van de dogmatische leerstellingen. ${ }^{55}$ En in 2017 was een enkele beschuldiging aan het adres

51 Kamali 1997, p. 132-43.

52 Zie o.a. de bespreking van A. Saeed, 'Pre-modern Islamic Legal Restrictions', in: A.M. Emon, M.S. Ellis \& B. Glahn (red.), Islamic Law and International Human Rights Law, Oxford 2010, p. 226-246), i.h.b. p. 245-246

53 R. Scott, The Challenge of Political Islam: Non-Muslims and the Egyptian State, Stanford 2010, p. 88.

54 T. Mahmud, 'Freedom of Religion \& Religious Minorities in Pakistan: A Study of Judicial Practice', Fordham International Law Journal 1995-1996, 19, p. 40-51, 62-85.

55 K. Bälz, 'Submitting Faith to Judicial Scrutiny through the Family Trial: The 'Abû Zayd case', Die Welt des Islams 1997, 2, 135-155. 
van de niet-islamitische gouverneur van Jakarta over vermeend oneerbied taalgebruik over de Koran voldoende om hem zijn verkiezing te laten mislopen. ${ }^{56}$

\section{Onmenselijke behandeling}

De islam predikt barmhartigheid en compassie. Niettemin bevat de islamitische rechtswetenschap enkele strafregels die zich slecht verhouden tot de hedendaagse opvattingen over menswaardigheid. Het gaat om een vijftal delicten die in de Koran staan vermeld - diefstal, straatroof, alcoholgebruik, overspel en valse beschuldiging van overspel - waar harde straffen op staan. Het zijn deze straffen, en niet zozeer de delicten, die als strijdig worden beschouwd met de mensenrechten: zweepslagen, steniging, amputatie van ledematen. ${ }^{57}$

In de hedendaagse rechtspraktijk geldt het islamitisch strafrecht - dat wil dus zeggen: de delicten met bijbehorende procesrecht en straffen - in een klein aantal moslimlanden: de meeste Golfstaten, Soedan, Iran, Pakistan, de Indonesische staat Atjeh en de noordelijke staten van Nigeria. ${ }^{58}$ De toepassing van dit strafrecht zien we voorts vooral in zogenoemde 'falende staten', waar islamitische organisaties vrij spel hebben.

\section{Bespreking}

Het voorgaande was slechts een grove schets van de verhouding tussen 'sharia' en 'mensenrechten', maar het geeft wel een goede algemene indruk van de onderwerpen en problemen waar we mee te maken hebben. We kunnen daaruit concluderen dat de sharia, geformuleerd als vastgestelde regels van de islamitische rechtswetenschap, niet de maximale eis haalt: deze regels zijn in veel gevallen strijdig met de belangrijkste bepalingen uit de mensenrechtenverdragen. Dat geldt in veel mindere mate als we de vergelijking maken met de hedendaagse rechtspraktijk van de meeste moslimmeerderheidslanden: met uitzondering van het religieus familierecht hebben de meeste van deze landen gekozen voor rechtsstelsels en -regels die overeenkomen met die van de internationale mensenrechten. Toch zijn er enkele conceptuele kwesties die nadere bespreking behoeven.

- Klassieke en sociale mensenrechten

De eerste kwestie betreft de keuze van de mensenrechten die hiervoor zijn besproken in samenhang met de mensenrechten. Deze zijn namelijk van het klassieke type, dat we kunnen karakteriseren met een terughoudende rol van de staat ten aanzien van de gedragingen van zijn burgers. Dit zijn ook bij uitstek de rechten waar de sharia in negatieve zin aan de orde komt. Niet besproken zijn echter de sociale mensenrechten, ofwel de rechten waar de staat een nadrukkelijke rol zou moeten spelen; het gaat dan om rechten als onderwijs, behuizing, werk. Het interessante is nu dat de sharia hier ook regelgeving over bevat. De eerderge-

56 Zie bijv. The Guardian, 'Jakarta Christian governor to face blasphemy trial over Islam insult claim’, 16 november 2017.

57 R. Peters, Crime and Punishment in Islamic Law. Theory and Practice from the Sixteenth to the Twenty-first Century, Cambridge 2005, p. 53-64. 
noemde 'barmhartigheid' is, als een van de kernwaarden van de islam, door vroege kaliefs en rechtsgeleerden uitgewerkt in regels van sociale zorg. ${ }^{59}$

$\mathrm{Nu}$ hadden de meeste moslimmeerderheidslanden in de vijftiger jaren een socialistisch systeem geïmplementeerd dat zich richtte op sociale zorg, gratis onderwijs en gezondheidszorg. Maar de islam speelde hier absoluut geen rol in. Integendeel, het waren tijden van strikt secularisme, en voor zover we kunnen spreken van sociale mensenrechten werden deze ingegeven door de ideologie van het socialisme, niet die van de islam. Sinds de jaren tachtig van de vorige eeuw heeft het socialistisch gedachtegoed echter afgedaan en wordt in toenemende mate over sociale en politieke kwesties gedacht in termen van de islam. Moderne moslimdenkers hanteren hierbij '(sociale) rechtvaardigheid' ('adala) en 'barmhartigheid' (rahma) als kernwaarden voor een billijke verdeling van economische middelen. ${ }^{60}$ Dit gedachtegoed heeft zich vooral ontwikkeld in de charitatieve sector, en nauwelijks op statelijk niveau. ${ }^{61}$

- De rol van internationale verdragen

Bijna alle moslimlanden hebben meerdere internationale mensenrechtenverdragen geratificeerd. Daarmee hebben zij zich gecommitteerd aan deze internationale standaarden, ongeacht hun visie op of zelfs implementatie van sharia. ${ }^{62}$ Het veelgehoorde argument dat deze internationale standaarden 'westers' zouden zijn, doet daarmee ook wat vreemd aan: door ondertekening van de verdragen hebben deze landen zich die standaarden immers eigen gemaakt. Ook het argument dat de internationale standaarden 'westers' zouden zijn omdat zij vooral door westerse landen opgesteld zouden zijn, wordt gelogenstraft door het feit dat moslimstaten al vanaf de Universele Verklaring van de Rechten van de Mens (1948) actief bij de totstandkoming daarvan betrokken waren. ${ }^{63}$

Er zit echter een addertje onder het gras, namelijk in de vorm van de uitzonderingen die lidstaten gerechtigd zijn om te maken op artikelen in de verdragen. Diverse moslimmeerderheidslanden hebben hier gebruik van gemaakt met verwijzingen naar islamitisch recht. ${ }^{64}$ Deze uitzonderingen kunnen zeer algemeen zijn geformuleerd ('mits niet strijdig met de islamitische sharia'), of iets minder algemeen ('mits niet strijdig met de familiewet'), of soms wordt een concreet artikel

59 Voor een uitgebreide beschouwing, zie het proefschrift van S. al-Daghistani, The Making of Islamic Economics, Leiden 2017.

60 Zie bijv. S. Qutb, Social Justice in Islam (vertaling), Oneonta 2015; M. Iqbal (red.), Distributive Justice and Need Fulfillment in an Islamic Economy, Islamabad/Manchester 1988; S.M. Hasanuz Zaman, Economic Functions of an Islamic State, Leicester 1991.

61 Zie bijv. J.A. Clark, Islam, Charity, and Activism: Middle-Class Networks and Social Welfare, Bloomington 2004.

62 Zie de analyse door K. Cavanaugh van 24 moslimlanden in het Midden-Oosten, inclusief Iran en Afghanistan, waaruit blijkt dat de meerderheid veel, of zelfs alle mensenrechtenverdragen heeft geratificeerd (K. Cavanaugh, 'Narrating Law', in: A.M. Emon, M.S. Ellis \& B. Glahn (red.), Islamic Law and International Human Rights Law, Oxford 2010, p. 17-51, i.h.b. p. 35-42).

63 S. Waltz, 'Universal Human Rights: The Contribution of Muslim States', Human Rights Quarterly 2004, 4, p. 799-844.

64 Cavenaugh 2010, p. 40-42; R. Cook, 'Reservations to the Convention on the Elimination of All Forms of Discrimination Against Women', 30 VA. J. INT'L L. 1990. 
genoemd dat het ratificerende land buiten toepassing stelt, waarbij in dat laatste geval strijdigheid met 'de islamitische sharia' als rechtvaardigingsgrond wordt opgevoerd. ${ }^{65}$

\section{- De pijnpunten}

Waarom doen moslimstaten, als het gaat om de mensenrechten, zo moeilijk over bepaalde onderwerpen en over andere niet? Hier worden door de desbetreffende staten geen duidelijke antwoorden op gegeven, maar twee verklaringen dienen zich aan. De eerste is dat een staat in tijden van islamitisch fundamentalisme de handen vrij wil hebben om gevoelige kwesties vrijelijk aan te kunnen pakken. De term 'sharia' is namelijk dusdanig ongedefinieerd, en leent zich voor zo veel interpretaties (afhankelijk van de conservatieve of liberale visie die men hanteert), dat het opnemen van de term 'sharia' in een grondwet of in een verdragsexceptie veel armslag oplevert, zowel politiek als juridisch.

De tweede verklaring ligt in de islam, en met name in de sharia. Want zelfs als een staat bereid zou zijn om regels van de islam aan te passen, is er een grote beer op de weg: regels die duidelijk in de Koran staan en waarvan de betekenis onomstotelijk vaststaat, ${ }^{66}$ zijn onveranderlijk en daar valt niet mee te marchanderen. In aanmerking nemende dat de Koran het letterlijke woord van God is, betreft het hier dus regels waarvan God in Zijn onnavolgbare wijsheid heeft besloten dat Hij deze van bijzonder groot belang vindt. De rechten van de man, zoals polygamie, eenzijdige scheiding en een dubbele erfportie, zijn daarmee onvervreemdbare, want door God gegeven rechten geworden. Zelfs een seculiere overheid zal het niet wagen om daartegen in te gaan, wat verklaart waarom geen enkel moslimland - met uitzondering van Turkije in $1923^{67}$ en Tunesië in 1956 en $2017^{68}$ ooit de stap heeft durven nemen om juist deze 'onomstotelijke' regels van het familierecht af te schaffen of grondig te hervormen.

We zullen in het navolgende zien dat enkele moslimintellectuelen menen dat zulke ingrijpende aanpassingen wel degelijk mogelijk zijn, zonder dat daarmee de beginselen van de islam geweld wordt aangedaan.

\section{Toekomst: maximaal of minimaal?}

In de voorgaande paragraaf zagen wij dat de maximale eis - overeenkomstigheid van sharia en mensenrechten - niet gehaald wordt als het gaat om de regels van

65 Het voert te ver om alle verdragen en alle uitzonderingen te vermelden. Een interessante illustratie is het document met alle uitzonderingen op de Conventie tot Eliminatie van Alle Vormen van Discriminatie tegen Vrouwen (CEDAW: https://documents-dds-ny.un.org/doc/UNDOC/GEN/ N06/309/97/PDF/N0630997.pdf?OpenElement).

66 Letterlijk: 'een duidelijke tekst die vaststaat in grondslag en in betekenis' ('nass sarih qati' althubut wa qati' al-dalala') - zie M.S. Berger, 'Apostasy and Public Policy in Contemporary Egypt: An Evaluation of Recent Cases from Egypt's Highest Courts', Human Rights Quarterly 2003, 3, p. 720-740, i.h.b. p. 726-727.

67 Turkije heeft het islamitisch familirecht integraal vervangen door het Zwitsers familierecht.

68 In 1956 schafte Tunesië polygamie af, en in 2017 het verbod op het huwelijk tussen een moslimvrouw met een niet-moslimse man. 
het klassieke shariarecht. De rechtspraktijk van moderne moslimmeerderheidslanden lijkt in dat opzicht wat meer veelbelovend, maar door de toenemende toepassing van islamitisch recht in hun systemen sinds de jaren tachtig ${ }^{69}$ is ook daar de maximale meetlat komen te zakken.

In de navolgende paragrafen richten we onze blik op de moslims die menen dat sharia en mensenrechten wél verenigbaar zijn. Er bestaan echter heel verschillende benaderingen van deze visie. De eerste categorie meent dat de sharia in onaangepaste vorm al voldoet aan de moderne mensenrechtencriteria, de tweede meent dat ingrijpende hervormingen in de sharia nodig zijn om dat doel te bereiken. Alvorens te bezien of we hier te maken hebben met een 'maximum'-standaard volgens welke sharia en mensenrechten kunnen samengaan, of dat er anders sprake kan zijn van een minimumstandaard die mondiaal gedeeld kan worden, is het van belang om deze twee visies nader te bekijken.

\section{Sharia behoeft geen aanpassing}

Degenen die menen dat de sharia in onaangepaste vorm al voldoet aan de moderne mensenrechtencriteria, spreken van 'islamitische mensenrechten'. Enerzijds geven zij daarmee aan dat ook de islam voldoet aan de universele eisen van mensenrechten, anderzijds maken zij duidelijk dat zij een 'eigen' vorm van mensenrechten hanteren, namelijk die van de islam. Met deze opvatting onderscheiden zij zich nadrukkelijk van wat zij aanduiden als 'westerse' mensenrechten. De voorstanders van deze mening scharen zich daarmee onder de pleitbezorgers van een cultuurrelativistische opvatting van mensenrechten, en scharen zich in de rijen van degenen die spreken van 'Afrikaanse' en 'Aziatische' mensenrechten ter onderscheid van de internationale mensenrechten die zij bestempelen als 'westers'. ${ }^{70}$

Een duidelijk voorbeeld van deze 'islamitische mensenrechten' zijn de regels die de Organisatie van de Islamitische Conferentie (OIC), die bijna alle moslimmeerderheidslanden verenigt, heeft opgesteld. De meest bekende daarvan is de OIC Conventie van Islamitische Mensenrechten van 1990, kortweg bekend als de 'Cairo Declaration' ${ }^{71}$ Deze conventie is zwaar bekritiseerd door mensenrechtenjuristen omdat zij in stijl en bewoordingen volledig lijkt te voldoen aan de internationale verdragen, maar bij nadere inspectie op cruciale punten daarvan afwijkt. ${ }^{72}$ Zo'n afwijking kan zijn dat termen worden gebruikt die niet worden gedefinieerd. Zo spreken artikelen 1 en 6 van de Cairo Declaration van 'menselijke waardigheid'

69 Elders noem ik dit de fase van 'Codificatie van het islamiseringsproject': 'Sharia and the Nation State', in: R. Peters \& P. Bearman (red.), The Ashgate Research Companion to Islamic Law, Farnham/Burlington: Ashgate Publishing 2014, p. 223-234, i.h.b. p. 226 e.v.

70 Zie voetnoot 20.

71 Zie voor de volledige (oorspronkelijke, Engelstalige) tekst: www.oic-iphrc.org/en/data/docs/legal_ instruments/OIC\%20Instruments/Cairo\%20Declaration/Cairo\%20Declaration\%20on \%20Human\%20Rights\%20in\%20Islam\%20-\%20EV.pdf.

72 Een van de meest uitgesproken critici is A.E.Mayer, Islam and Human Rights: Tradition and Politics, Londen: Taylor \& Francis 2012 (een samenvattende versie is te lezen in 'Universal versus Islamic Human Rights: A Clash of Cultures or Clash with a Construct', 15 Michigan Journal of International Law 1994). 
zonder aan te geven wat daarmee wordt bedoeld, zodat er een grote ruimte voor interpretatie overblijft:

Artikel 1: 'All men are equal in terms of basic human dignity and basic obligations and responsibilities, without any discrimination on the grounds of race, colour, language, sex, religious belief, political affiliation, social status or other considerations.'

Artikel 6: 'Woman is equal to man in human dignity, and has rights to enjoy as well as duties to perform.'

Een soortgelijk voorbeeld is het gebruik van de term 'sharia', wat, zoals wij hiervoor al zagen, een brede term is die voor velerlei uitleg vatbaar is. Artikelen 12 en 22 geven vrijheden die vervolgens als volgt worden beperkt:

Artikel 12: 'Every man shall have the right, within the framework of Shari'ah, to free movement.'

Artikel 22: 'Everyone shall have the right to express his opinion freely in such manner as would not be contrary to the principles of the Shari'ah.'

Artikel 12 heeft zeer waarschijnlijk betrekking op de situatie van de vrouw, waarvan conservatieve interpretaties van de sharia menen dat zij niet zonder toestemming van haar man de deur uit mag. In het geval van artikel 22 kunnen wij ons makkelijk voorstellen dat iedere vorm van kritiek op de islam, hoe opbouwend ook, niet getolereerd zal worden.

Een andere afwijking van de internationale verdragen wordt gerealiseerd door cruciale voorwaarden of eigenschappen weg te laten. Zo bepaalt artikel 5 van de Cairo Declaration:

Artikel 5: 'Men and women have the right to marriage, and no restrictions stemming from race, colour or nationality shall prevent them from enjoying this right.'

Wat in deze bepaling ontbreekt, is de eigenschap religie. En dat is niet toevallig: er geldt nu eenmaal de regel dat de moslimman wel met een niet-moslimse vrouw mag trouwen, maar omgekeerd is dat verboden. Dit is een onvervreemdbare regel (geen wonder dat de afschaffing van die regel in Tunesië in 2017 groot nieuws was), en door deze eigenschap uit het rijtje weg te laten kan deze regel gehandhaafd blijven.

De Cairo Declaration is een bijzondere tekst, in die zin dat hij keurig de stijl en bewoordingen van de internationale verdragen volgt, en tegelijkertijd de regels van de islam - weliswaar op indirecte wijze - handhaaft. Het is niet verwonderlijk 
dat de OIC werd verweten op heimelijke wijze te proberen islamitische regels in een internationaal acceptabel mensenrechtenjasje te steken. ${ }^{73}$

\section{Sharia behoeft nieuwe benadering}

Een kleine groep gelovige moslimintellectuelen is van mening dat er wel degelijk strijdigheid is tussen mensenrechten en enkele regels van de sharia zoals die nu algemeen aanvaard zijn, maar dat die strijdigheid opgeheven kan worden als er opnieuw gekeken wordt naar de rechtswetenschappelijke methodieken van de sharia. Deze intellectuelen redeneren als volgt: in de vroege islam hebben moslimgeleerden methodes ontwikkeld die volgens hen tot bepaalde regels leiden, maar dat zou ons, moslimgeleerden van nu, evenzeer het recht geven om die methodes opnieuw toe te passen, of zelfs opnieuw te ontwikkelen. Met deze benadering respecteren deze moslims dus de tekstuele bronnen - en daarbij gaat het vooral om de Koran -, maar veroorloven zij zich vrijheden ten aanzien van de menselijke omgang met die bron, net zoals hun voorgangers van eeuwen her dat hebben gedaan. In de woorden van een prominente denker op dit gebied, Khalid Abou El Fadl:

'I do believe that even if Islam has not known a human rights tradition similar to that developed in the West, it is possible, with the requisite amount of intellectual determination, analytical rigour, defiant social commitment, to demand and eventually construct such a tradition. ${ }^{74}$

Een kort overzicht van de wijzen waarop dit nieuwe denken wordt vormgegeven, illustreert de diversiteit in benaderingen:

a. De hiërarchie van bronnen

De Soedanese jurist Abdellahi An-Na'im meent dat de vroege moslimgeleerden ten onrechte een hiërarchie hebben aangebracht in de Koranische verzen waarbij de vaak gedetailleerde regels uit de tijd van Medina meer rechtskracht wordt toegeschreven dan de algemene regels uit de vroegere periode van Mekka. ${ }^{75} \mathrm{An}$ Na'im betoogt dat juist de Mekkaanse regels, die spreken over barmhartigheid en goede omgangsvormen, veel beter als inspiratie kunnen dienen voor de hedendaagse rechtsvinding omdat de regels van Medina te specifiek zouden zijn voor dat moment en die plek. An-Na'im had deze gedachte van zijn meester, Moham-

73 In de woorden van A.E. Mayer: 'They [de opstellers van de 'islamitische' mensenrechtenverklaringen; $\mathrm{MB}$ ] subordinate the borrowed international human rights provisions to newly-fashioned Islamic derogation clauses, circumscribing them by subjecting them to 'Islamic' conditions (...). [These 'Islamic' human rights'] formulations are designed to obscure the underlying intent to curb or deny human rights, employing wording that, unless closely scrutinized, might seem to be aimed at promoting them' (Mayer 2012, p. 325-26).

74 K. Abou El-Fadl, 'The Human Rights Commitment in Modern Islam', in: J. Runzo \& N. Martin (red.), Human Rights and Responsibilities, Oxford 2003, p. 154-55.

75 A. An-Na'im, Toward an Islamic Reformation: Civil Liberties, Human Rights and International Law, Syracuse 1990. 
med Taha, die in het fundamentalistische Soedan van de jaren tachtig voor deze opvatting de doodstraf heeft gekregen.

b. De historische context

Denkers als de Egyptische hoogleraar Koranstudies Nasr Aboe Zayd en de Marokkaanse filosoof Al-Jabri hebben betoogd dat de Koran vooral gelezen moet worden in zijn historische en lokale context. ${ }^{76}$ Al-Jabri geeft als voorbeeld de harde strafmaatregelen van de Koran: de hardvochtigheid van de straffen (amputatie, zweepslagen, steniging) kan volgens Al-Jabri verklaard worden met de historische omstandigheid dat men leefde in een harde, tribale samenleving, zonder politie of gevangenis, zodat de sociale orde op snelle en afdoende wijze hersteld moest worden. Maar die tijd is niet meer, zo vervolgt Al-Jabri, en we leven nu in maatschappijen met een justitieel apparaat en gevangenissen, zodat men wel het delict moet blijven vervolgen, maar dat men de strafmaatregelen kan aanpassen aan de moderne mogelijkheden. ${ }^{77}$

\section{c. De tekstuele interpretatie}

Een andere benadering die veel wordt toegepast is van taalkundige aard. Hierbij wordt de tekst van de Koran opnieuw geïnterpreteerd. Met name onder zogenoemde 'moslimfeministen' is dit een populaire methode. Amina Wadud en Margot Badran passen dit bijvoorbeeld toe op het beruchte vers waarin volgens de gangbare lezing zou staan dat mannen 'de opzichters' zijn van hun echtgenotes en zij gerechtigd zijn hen 'te slaan' in geval van 'ongehoorzaamheid'. ${ }^{78}$ Volgens de opvatting van Wadud en Badran moet echter gelezen worden dat mannen 'de beschermers' zijn van hun echtgenotes en zij gerechtigd zijn hen 'te vermanen' in geval van 'boze opstandigheid'. ${ }^{79}$ De reden van de vrouwonvriendelijke lezing van teksten, zo menen deze moslimfeministen - en dat zijn niet alleen vrouwen, overigens -, is dat de islamitische theologie en rechtsgeleerdheid eeuwenlang gedomineerd zijn geweest door mannen die vaak een conservatief beeld hadden van man-vrouwverhoudingen.

\section{d. De geest van de wet}

Een breed gedragen zienswijze is dat de Koranische verzen en regels niet in hun letterlijke betekenis gelezen moeten worden, maar dat meer gekeken moet worden naar de geest van de wet. Een veelgehoord argument is dat, aangezien God altijd wordt aangeduid als 'de Barmhartige, de Genadige', barmhartigheid en genade ook de pijlers van het geloof en zijn regels zouden moeten zijn. Ook deze zienswijze is populair bij 'moslimfeministen', die stellen dat de boodschap van de islam, in de context van de zevende eeuw, zeer vooruitstrevend en vrouwvriendeDen Haag 2006; M. Abid al-Jabri, Din, Dawla wa Sharia (Religie, Staat en Sharia), Beiroet 1996. Al-Jabri 1996, p. 175.

78 Koran 4:34.

79 A. Wadud, Qur'an and woman: rereading the sacred text from a woman's perspective, New York 1999: M. Badran, Feminism in Islam : secular and religious convergences, Londen 2009. 
lijk was. ${ }^{80}$ Dat de rechten, zoals toen geformuleerd, inmiddels als achterhaald zijn aan te merken, doet volgens deze moslimfeministen niet af aan de grondslag van deze rechten, namelijk dat zij progressief waren en bedoeld waren om de positie van vrouwen, niet-moslims en minderheden te beschermen. Deze grondslag zou dan als uitgangspunt moeten dienen voor nieuw te formuleren regels die recht doen aan de uitgangspunten van de islam.

e. De doelstellingen van de wet

Vergelijkbaar met de vorige benadering, maar meer ingebed in de gevestigde methodologie van de islamitische theologie, is de methode die bekendstaat als de maqasid al-sharia ('doelstellingen van de sharia'). Deze doelstellingen zijn hiervoor al kort besproken: het betreft de categorisering van rechten in drie categorieën van belangen die het welzijn van de mens dienen, namelijk dat wat noodzakelijk is, dat waar behoefte aan is, en dat wat het leven plezierig maakt. De 'noodzakelijke belangen' hebben prioriteit, en deze zijn onderverdeeld in de belangen van religie, leven, intellect, familie en eigendom. Het uitgangspunt van de gebruikers van deze methodiek is dat iedere islamitische regel moet beantwoorden aan deze doelstellingen. Dat uitgangspunt stelt hen vervolgens in staat om regels aan te passen. In deze optiek zijn mensenrechten niet het product van de doelstellingen van de islam, maar zijn het de doelstellingen zelf. ${ }^{81}$ Sommige denkers nemen dat nog een stap verder en combineren het maqasid-denken met het beginsel van 'algemeen belang' (maslaha) en komen zo tot een uitgebreid systeem van sociale mensenrechten. ${ }^{2}$

\section{Maximaal of minimaal?}

Wat leveren al deze zienswijzen op in termen van verenigbaarheid met het moderne mensenrechtendiscours? De kern van de onverenigbaarheid tussen islamitische regels en mensenrechten is niet óf en welke regels overeenkomen; waar het om draait is een aantal basisbeginselen, zoals gelijke behandeling en (volledige, zelfstandig uit te oefenen) vrijheid van religie, en dat deze zouden gelden voor iedereen, moslim en niet-moslim. Deze beginselen worden niet aanvaard door de vastgestelde regels van de islamitische rechtswetenschap, en evenmin door de 'islamitische mensenrechten'. Alleen als er een bereidheid is om deze beginselen te aanvaarden, kan er sprake zijn van een minimale maatstaf van waaruit toenadering - common ground - gevonden kan worden met het moderne mensenrechtendiscours. Het probleem is nu dat de regels die strijdig zijn met deze minimale maatstaf, zodanig verankerd liggen in de grondslagen van de islamitische theologie dat daar weinig beweging mogelijk lijkt: zij vormen de eerder besproken 'pijnpunten'.

80 Zie bijv. Musawah, CEDAW and Muslim Family Laws: In Search of Common Ground, 2012, p. 26 (www.musawah.org/sites/default/files/CEDAWMFLReport2012Edition_1.pdf).

81 J. Auda, Maqasid Al-Shariah as Philosophy of Islamic Law: A Systems Approach, Londen/Washington 2007, p. 23, 248.

82 A. Wajdi Dusuki \& N. Irwani Abdullah, 'Maqasid al-Shari'ah, Maslahah, and Corporate Social Responsibility,' The American Journal of Islamic Social Sciences 2007, 1, p. 25-45. 
Enkele moslimdenkers menen echter dat deze beweging wel mogelijk is doordat zij zich niet zozeer richten op het corpus van islamitische regels, maar op de uitgangspunten en methoden van waaruit men tot deze regels is gekomen. Hun methode van rechtsvinding levert meer op dan de positiefrechtelijke benadering van de voorstanders van de 'islamitische mensenrechten'. Deze denkers - laten we ze gemakshalve 'revisionisten' noemen - laten de uitgangspunten en methoden van de islamitische theologie als zodanig intact, maar eigenen zich het recht toe om, net als de vroege geleerden en exegeten, hier opnieuw mee aan de slag te gaan. Het gevolg van deze werkwijze is dat de revisionisten met nieuwe regels komen die nauwer aansluiten op de mensenrechten.

De revisionisten lijken vooralsnog echter een minderheidspositie te vertegenwoordigen en hebben veel kritiek te verduren. Vanuit de kringen van de gevestigde religieuze orde wordt hen verweten dat zij in het algemeen geen traditionele theologische opleiding hebben genoten en dus eigenlijk de kennis ontberen om dit soort ingrijpende voorstellen te doen. Het is inderdaad opvallend dat alle mensenrechtendenkers en -activisten die een islamitisch-theologische benadering bepleiten om tot een internationale mensenrechtenstandaard te komen, selfmade theologen zijn.

Daarnaast zijn er twee punten van kritiek van meer inhoudelijke aard. De eerste is dat het doel bij deze revisionisten de middelen zou heiligen: hen wordt verweten dat zij koste wat kost de sharia in overeenstemming willen brengen met de mensenrechten, en daartoe bereid zijn de sharia te buigen waar dat nodig mocht zijn zonder dat dit wordt gerechtvaardigd door de rechtsgeleerdheid van de sharia zelf. ${ }^{83}$ Deze buiging speelt ook zeker in het geval van terminologie: want hoewel men Koranische termen makkelijk zou kunnen vertalen met 'rechten', 'vrijheid', 'gelijkheid' of 'rechtvaardigheid', is het nog maar zeer de vraag of de hedendaagse betekenis van die woorden ook geldig is voor de terminologie van veertien eeuwen geleden. ${ }^{84}$

De revisionisten krijgen hier echter steun uit de hoek van de filosoof Joshua Cohen, die stelt dat de minimumstandaard voor mensenrechten alleen succesvol bereikt kan worden als vertegenwoordigers van diverse ethische tradities zich vinden in een aantal beginselen, zonder dat daarbij rekening wordt gehouden met de ethische traditie zelf. ${ }^{85}$ Deze beginselen moeten dus niet eerst vanuit de ethische traditie beredeneerd worden, maar juist van buitenaf bij consensus worden vastgesteld. ${ }^{86}$ Daarna is het aan iedere traditie om deze beginselen te verenigen met haar leerstellingen. Deze methode om te komen tot een minimumstandaard aan mensenrechten is lovenswaardig, maar lijkt mij vooral voorbehouden aan religieuze tradities met een sterke hiërarchie, waar consensus redelijk snel te bereiken is. Dat is echter niet het geval bij de soennitische islam. p. $185-215$, p. 3.

84 Moosa 2000/2001, p. 4. Zie ook de discussie hierover in par. 3.

85 Cohen 2004, p. 200.

86 Cohen (2004, p. 201-202) geeft het voorbeeld van de Rooms-Katholieke Kerk, die zich tijdens het Tweede Vaticaans Concilie in 1962 zich uitsprak voor religieuze vrijheid, ook al ging dat in tegen de gevestigde orthodoxie die de Kerk eeuwenlang had gevoerd. 
Een ander punt van kritiek is dat bij veel van de revisionistische methodes niet altijd evident is voor wie de mensenrechten bedoeld zijn: gaat het om mensenrechten die voor iedereen gelden maar een islamitische verantwoording hebben, of betreft het rechten die alleen gelden voor moslims? Het eerste lijkt het geval te zijn, maar het gebrek aan duidelijkheid hierover is een tekortkoming in dit discours. Want hoe je het ook wendt of keert, de islam is - net als de meeste religies - een exclusieve godsdienst, die zich richt tot zijn eigen gelovigen met uitsluiting van niet-gelovigen. Een van de weinige denkers die hier expliciet in is, is de prominente Syrische denker Muhammad Shahrour, die stelt: 'Moslims moeten de grondslagen van religieus geloof opnieuw bekijken, en de exclusieve islamitische boodschap herschrijven zodat het spreekt tot een wereldwijd, inclusief gehoor. ${ }^{\text {'7 }}$

\section{Conclusie}

De centrale vraag in dit artikel is of islam en mensenrechten verenigbaar zijn, hetzij in een 'maximale' vorm, namelijk dat de regels van beide rechtsstelsels overeenkomen of tenminste compatibel zijn, hetzij in een 'minimale' vorm, namelijk dat de onderliggende waarden overeenkomen. Het beeld dat we hebben geschetst van de praktijken en opvattingen over islam en mensenrechten geeft hier geen eenduidig antwoord op.

Een eerste conclusie die we kunnen trekken is dat het rechtsgeleerde islamitische recht, zoals geconcipieerd in de eerste eeuwen van de islam, zich slecht verhoudt tot de mensenrechten zoals wij die vandaag de dag vormgeven, zowel op minimaal als maximaal niveau. Als pluralisme en tolerantie de minimale eisen zouden zijn die men aan de mensenrechten wil stellen, ${ }^{88}$ dan kunnen wij beide waarden zeker terugvinden in de islam, maar in gelimiteerde vorm: in de islamitisch-theologische notie van religieus pluralisme worden weliswaar het jodendom en christendom erkend als voorlopers van de islam, maar worden non-monotheïstische godsdiensten verworpen. En de islamitische religieuze tolerantie is vooral bedoeld voor niet-moslims, en in veel mindere mate voor moslims zelf. Evenmin wordt tegemoetgekomen aan de maximale eis van mensenrechten, namelijk dat wordt voldaan aan de moderne mensenrechtelijke waarden en regels: de positivistische uitkomst van het rechtsgeleerde islamitische recht levert namelijk een scala aan regels op die zonder meer strijdig zijn met de huidige mensenrechten.

Deze negatieve conclusie zien we in mindere mate ook weerspiegeld in de hedendaagse rechtspraktijk van moslimmeerderheidslanden, afhankelijk van de mate waarin zij zich committeren aan het islamitisch recht. Dat is vooral het geval in familie- en erfrecht: de nationale wetgeving op dit gebied is in bijna alle moslimlanden gebaseerd op het islamitische recht, en juist hier spelen de islamitische regels een rol die een onderscheid maken naar religie en geslacht. Naarmate moslimmeerderheidslanden meer 'islamitische' regels invoeren, met name op het terrein van strafrecht en vrijheid van religie, raken de mensenrechten steeds meer in

87 The Concept of Freedom in Islam' (artikel is beschikbaar op verschillende internetsites, waaronder www.scribd.com/document/310526431/Shahrour-Freedom). 
het gedrang en wordt de lat omlaag geduwd van maximale naar minimale verwachtingen. Nationale wetgevers van deze landen mogen regelmatig proberen deze verschillen te dichten, en lidstaten van de Organisatie van de Islamitische Conferentie mogen hun handtekening zetten onder verklaringen van 'islamitische mensenrechten', maar deze maatregelen laten de essentie van de verschillen vaak onaangeroerd. Vandaar ook dat veel moslimlanden in het ratificeren van internationale mensenrechtenverdragen een voorbehoud maken, hetzij specifiek voor familierecht, hetzij in algemenere termen als 'mits niet strijdig met sharia'.

Bij deze sombere observatie past echter wel een kanttekening: niet alle islamitische regels zijn strijdig met mensenrechten. Integendeel, het gaat om een zeer klein aantal regels. Maar juist deze regels betreffen essentiële waarden in de mensenrechten. Niettemin moeten wij ons hoeden voor de valkuil waar het Europese Hof voor de Rechten van de Mens in stapte met de bewering dat 'sharia' strijdig is met mensenrechten. Dat is onjuist. Naast de enkele regels van de sharia die aanleiding geven tot onoverkomelijke problemen met mensenrechten, zijn er veel regels van de sharia die zich uitstekend verhouden tot de normen van de moderne wereld, inclusief die van de mensenrechten.

Een andere benadering van dit vraagstuk is om niet te kijken naar de regels die zijn geproduceerd door de rechtswetenschap of -praktijk, maar naar de oude islamitische methodiek van rechtsvinding. Hier zien we een groeiend aantal moslimstemmen die menen dat een herziening van die methodiek niet alleen geoorloofd is - het is immers mensenwerk, en niet door God voorgeschreven - maar vooral ook noodzakelijk. Onder deze revisionisten bestaat een breed spectrum aan zienswijzen hoe deze herziening kan plaatsvinden, en hoe deze kan leiden tot islamitische regels die voldoen aan de moderne mensenrechtenstandaarden. Waar de islamitische rechtswetenschap op het eerste gezicht weinig aanleiding gaf tot optimisme in termen van mensenrechten, zien de revisionisten die wetenschap juist bij uitstek als mogelijkheid om te komen tot aanpassingen van het islamitisch recht. Deze aanpak staat nog in de kinderschoenen en is niet onomstreden.

Op basis van het voorgaande kunnen we de vraag die centraal staat in dit artikel kort en bondig als volgt beantwoorden: nee, islam en mensenrechten zijn op bepaalde, essentiële punten in beginsel niet verenigbaar maar, ja, dat kunnen ze wel zijn. Dat 'kunnen' heeft zowel een theologische als een politieke dimensie. Theologisch moet er namelijk de bereidheid zijn om het islamitische rechtssysteem met frisse blik aan een nieuwe evaluatie te onderwerpen. Deze benadering vereist ook veel moed, want geeft aanleiding tot veel weerstand, en kan zelfs leiden tot levensbedreigende situaties. Daarmee verweven speelt ook een politieke dimensie. Want deze discussie gaat niet zozeer over de islam als zodanig, maar om de veronderstelde tegenstelling van 'islam' versus het 'Westen'. Het is deze tegenstelling die ook regelmatig door moslimstaten wordt opgevoerd om westerse kritiek op mensenrechtenschendingen te smoren. Degenen die pleiten voor de vereniging van islamitisch recht met mensenrechten worden dan al snel geframed in deze tweedeling van islam versus Westen: hen wordt verweten dat zij hun islamitische eigenheid verloochenen ten koste van een westerse levenswijze. De dis- 
cussie is dus in volle gang, en vanuit mensenrechtenoptiek is optimisme zeker op zijn plaats, maar er is nog een lange weg te gaan. 